\title{
REVIEW ON THE SIGNIFICANCE OF QUINAZOLINE DERIVATIVES AS BROAD SPECTRUM ANTI-CANCER AGENTS.
}

\author{
Reda R. Mabrouk ${ }^{1}$, Mohamed Ayman El-Zahabi ${ }^{1 *}$, Samar A. El-Kalyoubi ${ }^{1}$, Hazem A. \\ Mahdy ${ }^{1} \&$ Abdallah E. Abdallah ${ }^{1}$ \\ ${ }^{1}$ Department of Pharmaceutical Medicinal Chemistry \& Drug Design, Faculty of \\ Pharmacy (Boys), Al-Azhar University, Cairo, Egypt \\ corresponding author Email : malzahaby@azhar.edu.eg
}

\begin{abstract}
Cancer is one of the major causes of human mortality worldwide. A number of approved antineoplastic medications and treatment regimens are already working in the field, and several new compounds are in different phases of clinical trials. An extensive series of anticancer drugs exist in the market, and studies explained that these molecules are associated with different types of adverse side effects. The reduction of the cytotoxicity of drugs to normal cells is a major problem in anticancer therapy. Therefore, researchers around the globe are involved in the development of more efficient and safer anticancer drugs. An interesting output of extensive research is that the quinazoline scaffold and its various derivatives can be explored further as a significant class of cancer chemotherapeutic agents that has already shown promising activities against different tumors. In general, quinazoline derivatives have already occupied a crucial place in modern medicinal chemistry. Quinazoline is one of the most studied moieties in medicinal chemistry due to the wide range of biological properties such as the anticancer, antibacterial, anti-inflammatory, antimalarial and antihypertensive activities. The anticancer activity of this scaffold has been well established.
\end{abstract}

Keywords: Quinazoline, cancer, Immunomodulators, thymidylate enzyme, DNA inhibition, tubulin polymerization 


\section{Objectives}

The aim of this review is to compile and highlight the developments concerning the anticancer activity of quinazoline derivatives as well as to suggest some new aspects of the expansion of anticancer activity of novel quinazoline derivatives as anticancer agents in the near future.

\section{Results}

Exhaustive literature survey indicated that quinazoline derivatives are associated with properties of inhibiting EGFR, VEGFR, and thymidylate enzymes. It was also found to be involved in disturbing tubulin assembly. Furthermore, quinazoline derivatives have been found to inhibit critical targets such as DNA repair enzymes. These derivatives have shown significant activity against cancer.

\section{Introduction}

Cancer is one of the major causes of worldwide human mortality. A wide range of cytotoxic drugs is available on the market, and several compounds are in different phases of clinical trials. Many studies suggest that these cytotoxic molecules are also associated with different types of adverse side effects; therefore, researchers around the globe are involved in the development of more efficient and safer anticancer drugs. In recent years, quinazoline and its derivatives have been considered an important class of cancer chemotherapeutic agents that show promising activity against different tumors(Ahmad 2017). Quinazolines and their derivatives can exhibit an antitumor effect via: inhibition of receptor tyrosine kinases (for example, epidermal growth factor receptor - EGFR) (Alqasoumi, Al-Taweel et al. 2010), inhibition of tubulins (Chinigo, Paige et al. 2008), induction of apoptosis (Sirisoma, Pervin et al. 2010), inhibition of phosphatidylinositol-3-kinases (PI3K(Peng, Tu et al. 2016) and inhibition of ABC transporters to overcome the multidrug resistance of tumors (Krapf, Gallus et al. 2017).

Of all the above-mentioned spectrum of targets for the antitumor action of quinazolines and their derivatives, inhibitors of receptor tyrosine kinases (RTK), mostly EGFR inhibitors have received the greatest development. This specificity reflects, firstly, the current trend in oncology towards the creation of targeted anticancer drugs, and, secondly, the important role of RTK in vital activity of cells, including cancer cells (Marzaro, Guiotto et al. 2012), (Ravez, Castillo-Aguilera et al. 2015).

In this work, quinazoline derivatives of anti-cancer activity are classified according to the chemical structure as follows:

\section{4-Amino-quinazoline approved by FDA as EGFR inhibitors.}

Gefitinib (1), Erlotinib (2), and Afatinib (3), epidermal growth factor receptor (EGFR) inhibitors, had been approved for the treatment of non-small cell lung cancer (NSCLC) (Chen, Du et al. 2014). 
<smiles>COc1cc2ncnc(Nc3ccc(F)c(Cl)c3)c2cc1OCCCN1CCOCC1</smiles>

Gefitinib (1)<smiles>C#Cc1cccc(Nc2ncnc3cc(OCCOC)c(OCCOC)cc23)c1</smiles>

Erlotinib(2)<smiles>CN(C)C/C=C/C(=O)Nc1cc2c(Nc3ccc(F)c(Cl)c3)ncnc2cc1OC1CCCC1</smiles>

Afatinib(3)

\section{Another 4-amino-quinazoline derivative as anti-cancer}

A series of 1-(4-(bis(2-chloroethyl)amino)phenyl)urea derivatives (4a-c) was evaluated for their antitumor activity. They showed anticancer activities against human solid tumor breast carcinoma (MX-1) and colon carcinoma (HCT-116) more potent than the positive control (Cisplatin). Moreover, compounds (4a-c) displayed significant antiproliferative activity against lung carcinoma (H1299) and prostate carcinoma cell growth (PC3) at low micromolar concentrations (Marvania, Lee et al. 2011).<smiles>[R3]c1cc(Nc2ncnc3ccc(NC(=O)Nc4ccc(N(CCCl)CCCl)cc4)cc23)c([R])c([R1])c1[R]</smiles>

\begin{tabular}{|c|c|c|c|c|}
\hline Comp & R & R1 & R2 & R3 \\
\hline $4 \mathrm{a}$ & $\mathrm{H}$ & $\mathrm{OCH}_{3}$ & $\mathrm{OCH}_{3}$ & $\mathrm{OCH}_{3}$ \\
\hline 4b & $\mathrm{F}$ & $\mathrm{Cl}$ & $\mathrm{H}$ & $\mathrm{H}$ \\
\hline $4 \mathrm{c}$ & $\mathrm{H}$ & $\mathrm{Cl}$ & $\mathrm{F}$ & $\mathrm{H}$ \\
\hline
\end{tabular}

Marzaro and co-workers designed 4-biarylaminoquinazoline analogues. Compounds (57) acted as dual inhibitors. The synthesized 4-biarylaminoquinazoline analogues are promising examples of dual tyrosine kinase inhibitors and tubulin polymeraze inhibitor(Marzaro, Coluccia et al. 2014). 


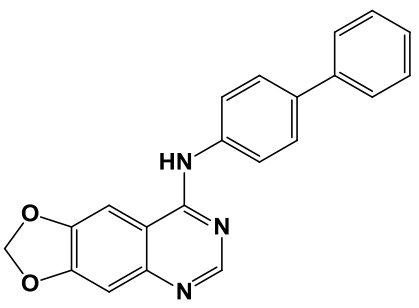

5

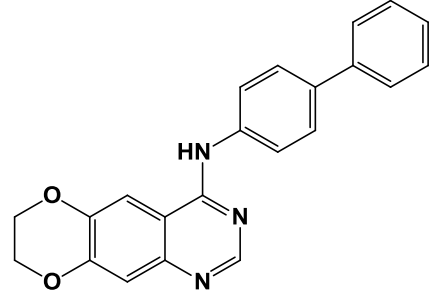

6

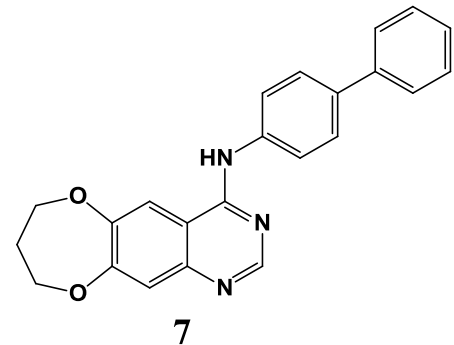

7

In 2013, 2-chloro-4-anilino-quinazolines were designed as EGFR and VEGFR-2 as dual inhibitors. EGFR inhibition was shown by compounds $8 \mathrm{a}$ d at $\left(\mathrm{IC}_{50}\right.$ range of $0.90 \mu \mathrm{M}$ $4.30 \mu \mathrm{M}$ ), while VEGFR-2 inhibition was reported to the same derivatives (8a-d) at ( $\mathrm{IC}_{50}$ range of $0.85 \mu \mathrm{M}-2.10 \mu \mathrm{M}$ ) (Hamed, Abou El Ella et al. 2013).

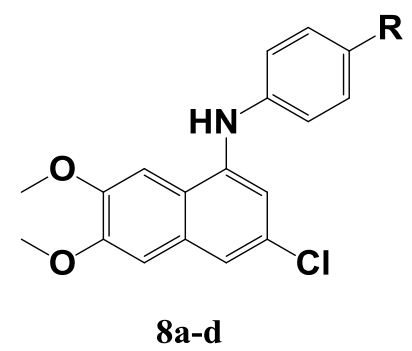

\begin{tabular}{|ll} 
COMP & R \\
\hline B & $\mathrm{SO}_{2} \mathrm{NH}_{2}$ \\
C & $\mathrm{SO}_{2} \mathrm{NHCH}_{3}$ \\
D & $\mathrm{OH}$ \\
& $\mathrm{CONH}_{2}$ \\
\hline
\end{tabular}

In 2020, a series of 4-anilinoquinazoline derivatives having disulfide moiety were designed, synthesized and evaluated as potent EGFR inhibitors. The results demonstrated that the most active compound (9) with $\mathrm{GI}_{50} 0.78 \mu \mathrm{M}$. against NSCLC cell line H3255 bearing EGFR mutant (Zheng, Zhang et al. 2020). 


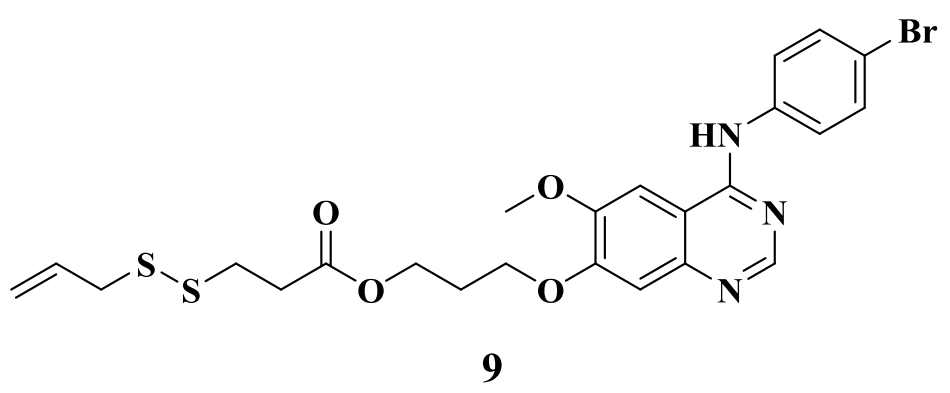

\section{4-Aminoquinazoline containing semicarbazide and thiosemicarbazide}

In 2012, a series of novel derivatives of quinazoline containing thiosemicarbazide moiety have been synthesized and tested for their antitumor activities in vitro against a panel of five human cancer cell lines. Compounds 10a-c showed the more potent inhibitory activity with IC50 $2.33 \quad 0.62 \mu \mathrm{M}, 2.51 \quad 0.81 \mu \mathrm{M}$ and $1.87 \quad 0.40 \mu \mathrm{M}$ respectively against CNE2 (nasopharyngeal carcinoma cell) (He, Wang et al. 2012).<smiles>[R]c1ccc(C(=O)NC(=S)NNc2ncnc3ccccc23)cc1</smiles>

10a-c

Wufu Zhu synthesized a new quinazoline analogues bearing aryl semicarb-azone scaffolds as potent EGFR inhibitors and found The most promising compound 11 showed the best activity against A549, HepG2, MCF-7 and PC-3 cancer cell lines and EGFR kinase, with the $\mathrm{IC}_{50}$ values of $1.32 \pm 0.38 \mu \mathrm{M}, 0.07 \pm 0.01 \mu \mathrm{M}, 0.91 \pm 0.29 \mu \mathrm{M}$ and $4.89 \pm 0.69 \mu \mathrm{M}$, which were equal to more active than afatinib $(1.40 \pm 0.83 \mu \mathrm{M}$, $1.33 \pm 1.28 \mu \mathrm{M}, 2.63 \pm 1.06 \mu \mathrm{M}$ and $3.96 \pm 0.59 \mu \mathrm{M}$ ), respectively ( $\mathrm{Tu}$, Wang et al. 2017). 
<smiles>O=C(N/N=C/c1ccc(O)cc1)Nc1cc2c(Nc3ccc(Cl)c(F)c3)ncnc2cc1OC1CCOC1</smiles>

A series of novel quinazoline derivatives containing thiosemicarbazide moiety were evaluated for their antitumor activity. It was reported that compounds (12a-c) showed significant in vitro cytotoxic activities against (KB) human oral carcinoma, (CNE2) human nasopharyngeal carcinoma, (MGC803) human gastric carcinoma, (MCF-7) human breast adenocarcinoma and (GLC-82) human lung cancer (He, Wang et al. 2012).<smiles></smiles>

\begin{tabular}{|ll|}
\hline COMP & $\mathbf{R}$ \\
\hline $12 a$ & $2 \mathrm{Cl}$ \\
$12 \mathrm{~b}$ & $\mathbf{2 F}$ \\
$\mathbf{2 c}$ & $\mathbf{4 C l}$ \\
\hline
\end{tabular}

Quinazoline compounds containing piperazine moiety

Tandutinib (CT53518) (13) is a quinazoline analogue containing piperazine moiety has been entered phase II clinical trials for the treatment of myeloid leukemia and advanced myelodysplasia (Knesl, Röseling et al. 2006). 


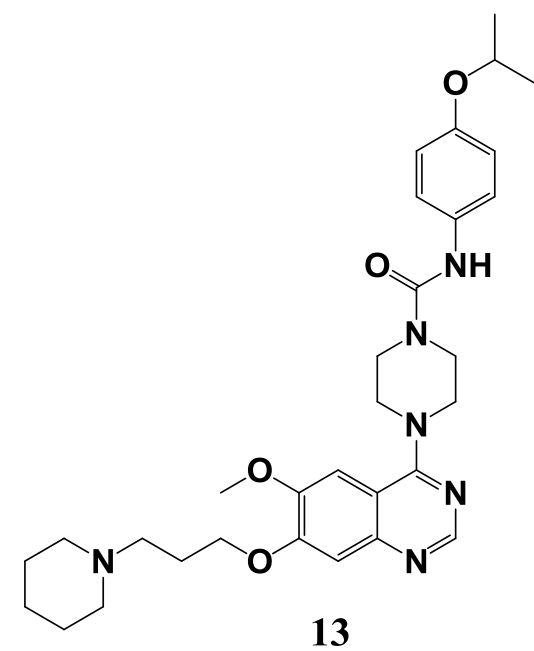

Wu et al. synthesized piperazine containing quinazolinone derivatives. Upon evaluation of the antitumor activities, compounds 14 and 15 showed promising activities with $\mathrm{IC}_{50}$ values of 0.11 and $2.01 \mu \mathrm{M}$, respectively. Moreover, compounds 14 and 15 were found to have significant potency against the HOP-92 cancer cell line with $\mathrm{IC}_{50}$ values of 0.11 and 1.70 $\mu \mathrm{M}$, respectively. Accordingly, the introduction of piperazinyl acetamide at position 7 of quinazoline revealed an effective anticancer scaffold (Wu, Xie et al. 2010).<smiles>CC(c1ccccc1)n1cnc2cc(NC(=O)CN3CCN(C)CC3)c(OCc3ccccc3)cc2c1=O</smiles>

14<smiles>COc1ccc(CCn2cnc3cc(NC(=O)CN4CCN(C)CC4)c(OCc4cc(C)cc(C)c4)cc3c2=O)cc1OC</smiles>

15

In 2016, Sheng-Li Cao and Xingzhi Xu have synthesized a series of quinazoline derivatives bearing piperazine-1-carbodithioate moiety at the C4-position. They reported that fourteen of twenty-six final compounds inhibited the proliferation of human lung cancerA549, breast adenocarcinoma MCF-7, and colorectal cancer HCT-116 cancer cell lines with $\mathrm{IC}_{50}$ values less than $10 \mu \mathrm{M}$. In particular, compound 16 which also found to HCT-116 cells at G0/G1 phase of the cell cycle(Zhang, Yang et al. 2016). 


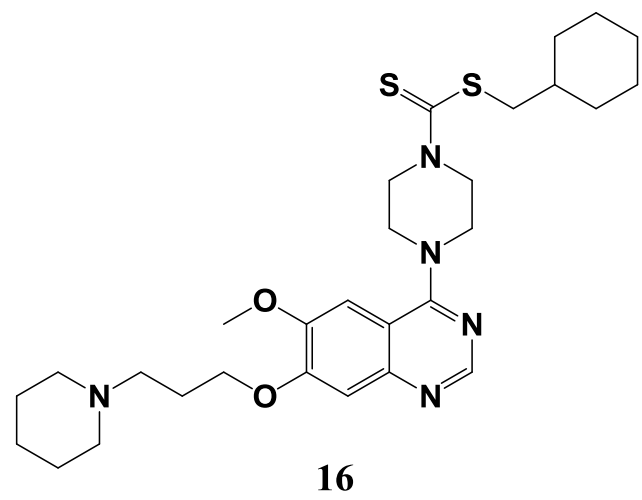

A series of novel quinazoline derivatives containing piperazine analogs were synthesized and evaluated for their anti-proliferative activities against A549, HepG2, K562, and PC-3 cell lines. Compound iv showed biological activity almost equal to that of the control, Gefitinib with $\mathrm{IC}_{50}$ values less than $10 \mu \mathrm{M}$ (Li, Chen et al. 2020).<smiles>COc1cc2ncnc(N3CCN(CC(=O)Nc4cccc(Cl)c4)CC3)c2cc1OCCCN1CCOCC1</smiles>

17

\section{Quinozolines containing sulphonamide moiety:}

In 2015, Compound 18 was identified as a potent compound exhibiting an $\mathrm{IC}_{50}$ value of $2.51 \mu \mathrm{M}$ on the NCI cell line. Whereas The reference drug (methotrexate) exhibited an $\mathrm{IC}_{50}$ value of $2.4 \mu \mathrm{M}$ (Zayed, Ahmed et al. 2015).<smiles>Cc1cc(NS(=O)(=O)c2ccc(-n3c(C)nc4ccc(F)cc4c3=O)cc2)ncn1</smiles>

18

In 2016, novel quinazoline-sulfonamide hybrids were synthesized and their in vitro anticancer activity was evaluated on four human cancer cell lines namely, lung cancer cell line (A549), cervical (HeLa) cancer cell line, colorectal cell line (LoVo) and breast cancer cell line (MDA-MB-231) using doxorubicin as reference drug. It was found that two candidates (compounds 19 and 20) showed effectiveness on the four cell lines, the 
active compounds could be considered as useful templates for further development to obtain more potent anticancer agent (Ghorab, Alsaid et al. 2016).<smiles>O=S(=O)(Nc1ccnn1-c1ccccc1)c1ccc(Nc2nc(-c3ccccc3)nc3ccccc23)cc1</smiles>

19<smiles>O=S(=O)(Nc1ccc2cn[nH]c2c1)c1ccc(Nc2nc(-c3ccccc3)nc3ccccc23)cc1</smiles>

Al-Obaid, A.M., et al have synthesized some of new 2-thieno-4(3H)-quinazolinone derivatives. They reported their biological evaluation as antitumor agents. Compound (21) 2-(2-thieno)-4-[4-sulfonam-iodobenzyl-amino]-6-iodo-quinazoline was the most active member for inhibition of EGFR and was evaluated against pancreatic (Miapaca2) and prostate (DU145) cancer cell lines for in vitro antitumor activity compared with parent Gefitinib (Al-Obaid, Abdel-Hamide et al. 2009).

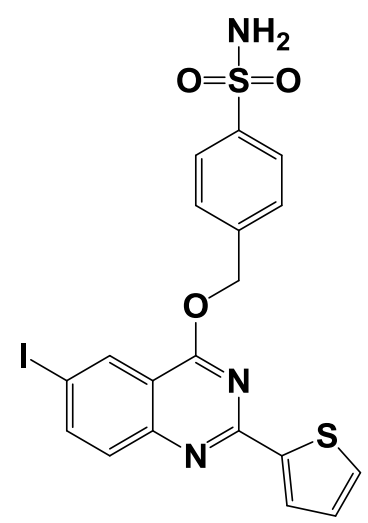

21

\section{Quinazoline containing triazolo moiety}

New series of triazolo [4,3-c]quinazolines were designed, synthesized as EGFR inhibitors. The synthesized derivatives were evaluated for their in vitro antitumor activity against HepG2, MCF7, PC-3, HCT-116 and HeLa cancer cell lines. ELISAbased EGFR-TK assay was performed for the most promising hybrids using Gefitnib as a reference drug. The results revealed that compounds 22, 23 and 24 exhibited strong EGFR inhibitory activity (Ewes, Elmorsy et al. 2020). 
<smiles>N#CC1=C(N)N(c2nnc3c4ccccc4nc(Sc4ccc(Br)cc4)n23)C(=O)C1</smiles>

22<smiles>O=C1CSCC(=O)N1c1nnc2c3ccccc3nc(Sc3ccc(Br)cc3)n12</smiles>

23<smiles>Nc1csc(Nc2nnc3c4ccccc4nc(Sc4ccc(Br)cc4)n23)n1</smiles>

24

Banerji, B., et al synthesized A series of triazole-substituted quinazoline hybrid molecules as anticancer agents. The results showed that compound (25) has moderate to good antiproliferative effects against four different cell lines HCT116, HepG2, PC-3, and MCF-7 (Banerji, Chandrasekhar et al. 2018).

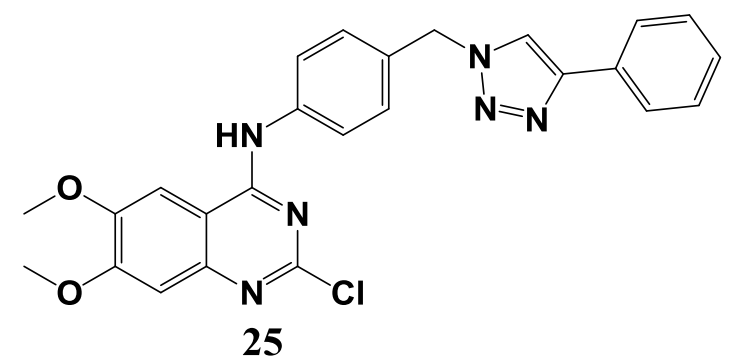

New series of triazolo[4,3-c]quinazolines were designed, synthesized and evaluated for their in vitro antitumor activity against HepG2, MCF7, PC-3, HCT-116 and HeLa cancer cell lines using MTT assay. It was found that all compounds showed variable in vitro cytotoxicity. Distinct derivatives exhibited higher inhibitory activity against the tested cell lines with $\mathrm{IC}_{50}$ values ranging from 8.27 to $10.68 \mu \mathrm{M}$ using DOX standard $\left(\mathrm{IC}_{50}=4.17-8.87 \mu \mathrm{M}\right)$. In vitro epidermal growth factor receptor (EGFR) inhibition assay was performed. Results revealed that compounds 26 and 27 exhibited worthy EGFR inhibitory activity with $\mathrm{IC}_{50}$ values ranging from 0.69 to $1.8 \mu \mathrm{M}$ in comparison to the reference drug Gefitinib $\left(\mathrm{IC}_{50}=1.74 \mu \mathrm{M}\right)$. Further investigation showed that active candidates 26 and 27 caused cell cycle arrest at the G2/M phase, and interestingly, induced cell death by apoptosis of MCF-7 cells cumulatively with 7.14 and $17.52 \mu \mathrm{M}$ respectively, compared with DOX as a positive reference (29.09\%) (Ewes, Elmorsy et al. 2020). 
<smiles>Clc1nc2ccccc2c2nnc(/N=C/c3ccco3)n12</smiles>

26<smiles>N#CC1=C(N)N(c2nnc3c4ccccc4nc(Sc4ccc(Br)cc4)n23)C(=O)C1</smiles>

27

\section{Quinazoline containing morpholine moiety}

Gefitinib (Iressa $\left.{ }^{\circledR}\right)(1)$ is one of quinazoline analogue containing morpholine moiety approved by FDA on May, 2003 as monotherapy for the treatment of patients having locally advanced or metastatic non-small cell lung cancer (NSCLC) after failure of both platinum-based and docetaxel chemotherapies. Iressa was found to cause significant shrinkage in tumors in about $10 \%$ of patients (Ismail, Ismail et al. 2016).

Peng, W., et al have synthesized a series of novel 7 or 8-substituted 4-morpholinequinazoline derivatives. Their PI3Ka inhibitory activities, antiproliferative activities against seven cancer cell lines, namely, PC-3, DU145, MCF-7, BT474, SK-BR-3, U937 and $\mathrm{A} 431$, were evaluated in vitro. and reported that Compound 28 proved to be a potent compound candidate with high PI3Ka inhibition activity $\left(\mathrm{IC}_{50} 1 / 44.2 \mathrm{nM}\right.$ ) and good antiproliferative activity. Compound 28 was also tested for its inhibitory activities against other kinases, such as PI3Kb, PI3Kg, PI3Kd and mTOR, its effects on p-Akt (S473) and cell cycle (Peng, Tu et al. 2016).<smiles></smiles>

28

In 2016 a series of novel morpholin-3-one fused quinazoline derivatives were designed, synthesized and their biological activities were evaluated. Most compounds showed good inhibitory activities against EGFR ${ }^{\mathrm{wt}}$ kinase $(\mathrm{IC} 50<1 \mu \mathrm{M})$. Among them, compound 29 demonstrated the most potent inhibitory activity $\left(\mathrm{IC}_{50}=53.1 \mathrm{nM}\right.$ against EGFR $^{\text {wt }}$ kinase) (Qin, Lv et al. 2016). 


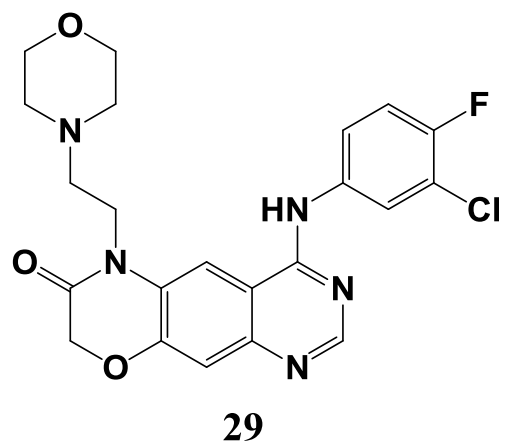

Yin, S., et al synthesized a novel quinozoline derivatives as anti-proliferative activity and demonstrated compound 30 and 31 also had well exhibition to excellent antiproliferation activity against human lung adenocarcinoma cell line (A549) and human breast cancer cell line (SK-Br3), and 31 also exhibited the lowest toxicity against Human Embryonic Lung Fibroblast cell line (HELF) cell. Finally, compound 31 presented remarkably higher inhibition efficacy towards tumor growth than Lapatinib in a mouse Lewis Lung Cancer (LLC) xenograft model (Yin, Tang et al. 2016).<smiles>O=C(CCl)OCn1c(=O)oc2cc3c(cc21)C(Nc1ccc(N2CCOCC2)c(Cl)c1)NC=N3</smiles>

30<smiles>O=C(CBr)OCn1c(=O)oc2cc3c(cc21)C(Nc1ccc(N2CCOCC2)c(Cl)c1)NC=N3</smiles>

31

Smaill, J.B., et al synthesized novel quinazoline derivatives as Tyrosine Kinase Inhibitors. Irreversible Inhibitors of the Epidermal Growth Factor Receptor and one derivative compound 32 (CI 1033) has been selected for clinical evaluation (Smaill, Rewcastle et al. 2000).<smiles>CCC(=O)Nc1cc2c(Nc3ccc(F)c(Cl)c3)ncnc2cc1OCCCN1CCOCC1</smiles>

32

\section{Quinazoline containing triazine moiety}

In 2020 hybrid quinazoline-1,3,5-triazine derivative as EGFR inhibitors, which were synthesized and tested by using a variety of in vitro, in silico, and in vivo techniques. The derivatives were found to be active against different cancer cell lines and nontoxic against normal ones, and compound $3 r$, showed a marginal potency against MCF-7 
$\left(\mathrm{IC}_{50}=17.2 \mu \mathrm{M}\right), \quad$ HeLa $\quad\left(\mathrm{IC}_{50}=17.3 \mu \mathrm{M}\right), \quad$ HepG2 $\quad\left(\mathrm{IC}_{50}=15.1 \mu \mathrm{M}\right), \quad$ and HL-60 $\left(\mathrm{IC}_{50}=14.3 \mu \mathrm{M}\right)$ respectively (Pathak, Rimac et al. 2021).<smiles>Cc1nc2cc(Br)ccc2c(=O)n1-c1ccc(Nc2nc(NC(N)=O)nc(N3CCOCC3)n2)cc1</smiles>

\section{Quinazoline containing piperdine moiety}

Vandetanib (Caprelsa ${ }^{\circledR)}$ (34) quinazoline analog containing piperidine moiety it is used for treatment of metastatic medullary thyroid cancer. Vandetanib was approved by FDA on April, 2011 (Kalyan, Vijay et al. 2014).<smiles>COc1cc2c(Nc3ccc(Br)cc3F)ncnc2cc1OCC1CCN(C)CC1</smiles>

2-\{3-[4-(4-Fluorophenyl)-3,6-dihydro-1(2H)-pyridinyl]propyl $\}$-8-methyl-4-(3H)quinazolin-one (35) was identified by Kinoshita and co-workers as potent PARP1 inhibitor with an $\mathrm{IC}_{50}$ value of $14 \mathrm{nM}$ Poly (ADP-ribose) polymerase-1 (PARP-1) is involved in many fundamental processes, including DNA repair and transcriptional regulation (Kinoshita 2004).<smiles>Cc1cccc2c(=O)[nH]c(CCCN3CCC(c4ccc(F)cc4)CC3)nc12</smiles>

Out of all the synthesized derivatives, the most active compound was N-(1benzylpiperidin-4-yl)-2-(4-phenylpiperazin-1-yl) quinazolin-4-amine (36) when tested on human lymphoma U-937 and RAJI cells. It induced the highest proliferation arrest and cell death induction starting from $10 \square \square \mathrm{M}$, in agreement with its DNMT3A inhibitory potency (Garofalo, Goossens et al. 2010). 


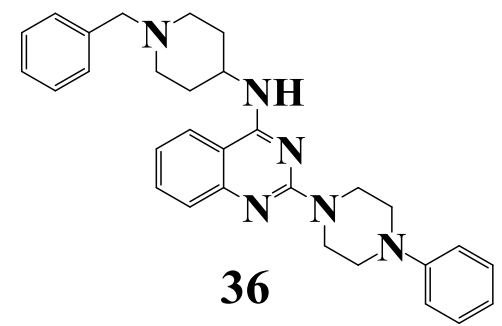

A series of novel C-5 substituted aniline quinazoline derivatives containing piperdine moiety displayed superior EGFR inhibitory activity at nanomolar concentration, compounds (37) and (38) results at ( $\mathrm{IC}_{50}$ values $21 \mathrm{nM}$ and $10 \mathrm{nM}$, respectively) (Ballard, Bradbury et al. 2006).<smiles>COc1cc2ncnc(Nc3ccc(F)c(Cl)c3)c2cc1OC1CCN(C)CC1</smiles>

37<smiles>COc1cc2ncnc(Nc3ccc(F)c(Cl)c3)c2cc1OC1CCNCC1</smiles>

38

\section{Quinazoline containing oxazole moiety}

Jian-Ping Yong synthesized 14 novel structures of isoxazole moiety containing quinazoline derivatives for the first time and in vitro anticancer activity was preliminarily evaluated. Compounds 39a, 39b, 39c and 39d exhibited the more potent and a broad spectrum of anticancer activity against A549, HCT116 and MCF-7 cell lines, which can be regarded as the promising drug-candidates for development of anticancer drugs (Yong, Lu et al. 2015).<smiles>[R4]c1cccc(-c2cc(COc3cc([R3])cc4cc([R2])c([R])cc34)on2)c1</smiles> 


\begin{tabular}{|c|c|c|c|c|}
\hline & $\mathrm{R} 1$ & $\mathrm{R} 2$ & $\mathrm{R} 3$ & $\mathrm{R} 4$ \\
\hline $39 \mathrm{a}$ & $\mathrm{H}$ & $\mathrm{H}$ & $\mathrm{Ph}$ & $2-\mathrm{Cl}$ \\
\hline $39 \mathrm{~b}$ & $\mathrm{OCH}_{3}$ & $\mathrm{OCH}_{3}$ & $\mathrm{Cl}$ & $4-\mathrm{CH}_{3}$ \\
\hline $39 \mathrm{c}$ & $\mathrm{OCH}_{3}$ & $\mathrm{OCH}_{3}$ & $\mathrm{Cl}$ & $2-\mathrm{Cl}$ \\
\hline $39 \mathrm{~d}$ & $\mathrm{OCH}_{3}$ & $\mathrm{OCH}_{3}$ & $\mathrm{Cl}$ & $2,4-\mathrm{diCl}$ \\
\hline
\end{tabular}

2014 a series of quinazoline derivatives possessing oxazole scaffold have been designed and synthesized, and their biological activities were also evaluated as potent EGFR inhibitory firstly and then anticancer activity. Compound 40 demonstrated the most potent inhibitory activity $\left(\mathrm{IC}_{50}=0.95 \mu \mathrm{mol} / \mathrm{L}\right.$ for EGFR and $2.53 \mu \mathrm{mol} / \mathrm{L}$ for A431 cells proliferation), which could be optimized as a potential EGFR inhibitor and anticancer drug in the further study (Hou, Zhang et al. 2014).<smiles>Clc1cc(Nc2ncnc3ccc(Nc4ncc(COc5ccccc5)o4)cc23)ccc1OCc1nccs1</smiles>

2018 Six series of quinazoline derivatives bearing an oxazole or imidazole moiety were designed, synthesized and evaluated for $\mathrm{IC}_{50}$ values against three cancer cell lines (A549, MCF-7 and PC-3). Most of the thirty-five target compounds showed excellent anti profelirative activity three selected compounds bearing oxazole moiety (40, 41 and 42) were further evaluated for the inhibitory activity against EGFR kinases and all of them exhibited excellent activity with the $\mathrm{IC}_{50}$ values at the nanomole level compared with afatinib (OuYang, Wang et al. 2018).<smiles>c1ccc2c(c1)CCCN2c1ncc2cc3nc(N4CCCCC4)oc3cc2n1</smiles>

41<smiles>CN(C)c1nc2cc3cnc(N4CCc5ccccc54)nc3cc2o1</smiles>

42 


\section{Conclusion}

Quinazolinone is an important pharmacophore, which is considered to be a privileged structure in medicinal chemistry. These structures represent molecules, which are capable of binding at multiple sites with high affinity and facilitate more rapid discovery of useful medicinally active compounds. Alfuzosine hydrochloride, prazosin hydrochloride, doxazosine mesylate and terazosine hydrochloride are approved drugs with quinazolinone structure in the market. Cytotoxic activity of the quinazolinone derivatives on various cell lines, for example, HeLa, L1210, and HT29, has also been reported. Gefitinib (Iressa ${ }^{\circledR}$ ) and erlotinib are derivatives of quinazolinones introduced to the market as anticancer agents. For cancer treatments, Quinazoline derivatives seem to be quite promising and act through various mechanisms that are well established. A lot of potentials are still hidden, which demands to be discovered for upgrading quinazoline derivatives efficacy. We can summarize that the properties of substituted quinazolines depend largely on (a) the nature of the substituents, (b) whether they are in the pyrimidine ring or in the benzene ring, and (c) whether or not complete conjugation is present in the pyrimidine ring. This review has shown that quinazoline derivatives can further be explored for the betterment of chemotherapy. Future investigation of quinazolinone structure could give some more hopeful results in the field of medicinal chemistry

\section{REFERENCES}

Ahmad, I. (2017). "An insight into the therapeutic potential of quinazoline derivatives as anticancer agents." MedChemComm 8(5): 871-885.

Al-Obaid, A. M., S. G. Abdel-Hamide, H. A. El-Kashef, A.-M. Alaa, A. S. El-Azab, H. A. Al-Khamees and H. I. El-Subbagh (2009). "Substituted quinazolines, part 3. Synthesis, in vitro antitumor activity and molecular modeling study of certain 2-thieno-4 (3H)-quinazolinone analogs." European journal of medicinal chemistry 44(6): 2379-2391.

Alqasoumi, S. I., A. M. Al-Taweel, A. M. Alafeefy, M. M. Ghorab and E. Noaman (2010). "Discovering some novel tetrahydroquinoline derivatives bearing the biologically active sulfonamide moiety as a new class of antitumor agents." European journal of medicinal chemistry 45(5): 1849-1853.

Ballard, P., R. H. Bradbury, C. S. Harris, L. F. Hennequin, M. Hickinson, P. D. Johnson, J. G. Kettle, T. Klinowska, A. G. Leach and R. Morgentin (2006). "Inhibitors of epidermal growth factor receptor tyrosine kinase: Novel C-5 substituted anilinoquinazolines designed to target the ribose pocket." Bioorganic \& medicinal chemistry letters 16(6): 1633-1637.

Banerji, B., K. Chandrasekhar, K. Sreenath, S. Roy, S. Nag and K. D. Saha (2018). "Synthesis of triazole-substituted quinazoline hybrids for anticancer activity and a lead compound as the EGFR blocker and ROS inducer agent." omega 3(11): 16134-16142. 
Chen, X., Y. Du, H. Sun, F. Wang, L. Kong and M. Sun (2014). "Synthesis and biological evaluation of novel tricyclic oxazine and oxazepine fused quinazolines. Part 1: erlotinib analogs." Bioorganic \& medicinal chemistry letters 24(3): 884-887.

Chinigo, G. M., M. Paige, S. Grindrod, E. Hamel, S. Dakshanamurthy, M. Chruszcz, W. Minor and M. L. Brown (2008). "Asymmetric synthesis of 2, 3-dihydro-2-arylquinazolin-4-ones: methodology and application to a potent fluorescent tubulin inhibitor with anticancer activity." Journal of medicinal chemistry 51(15): 4620-4631.

Ewes, W. A., M. A. Elmorsy, S. M. El-Messery and M. N. Nasr (2020). "Synthesis, biological evaluation and molecular modeling study of [1, 2, 4]-Triazolo [4, 3c] quinazolines: New class of EGFR-TK inhibitors." Bioorganic \& medicinal chemistry 28(7): 115373.

Garofalo, A., L. Goossens, B. Baldeyrou, A. Lemoine, S. Ravez, P. Six, M.-H. I. n. David-Cordonnier, J.-P. Bonte, P. Depreux and A. I. Lansiaux (2010). "Design, synthesis, and DNA-binding of $\mathrm{N}$-alkyl (anilino) quinazoline derivatives." Journal of medicinal chemistry 53(22): 8089-8103.

Ghorab, M. M., M. S. Alsaid, M. S. Al-Dosari, M. G. El-Gazzar and M. K. Parvez (2016). "Design, synthesis and anticancer evaluation of novel quinazolinesulfonamide hybrids." Molecules 21(2): 189.

Hamed, M. M., D. A. Abou El Ella, A. B. Keeton, G. A. Piazza, M. Engel, R. W. Hartmann and A. H. Abadi (2013). "Quinazoline and tetrahydropyridothieno [2, 3-d] pyrimidine derivatives as irreversible EGFR tyrosine kinase inhibitors: influence of the position 4 substituent." MedChemComm 4(8): 1202-1207.

He, J., X. Wang, X. Zhao, Y. Liang, H. He and L. Fu (2012). "Synthesis and antitumor activity of novel quinazoline derivatives containing thiosemicarbazide moiety." European journal of medicinal chemistry 54: 925930.

Hou, X., J. Zhang, X. Zhao, L. Chang, P. Hu and H. Liu (2014). "Design, synthesis and bioactivities evaluation of novel quinazoline analogs containing oxazole units." Chinese Journal of Chemistry 32(6): 538-544.

Ismail, R. S., N. S. Ismail, S. Abuserii and D. A. Abou El Ella (2016). "Recent advances in 4-aminoquinazoline based scaffold derivatives targeting EGFR kinases as anticancer agents." Future Journal of Pharmaceutical Sciences 2(1): 9-19.

Kalyan, D., M. Vijay, V. Sravanthi, S. Sathyanarayana and C. Meher (2014). "Medications of Quinazolines and Quinoxalines (Qs \& Qs): An overview." PharmaTutor 2(8): 179-187. 
Kinoshita, T. (2004). "Inhibitor-induced structural change of the active site of human poly (ADP-ribose) polymerase." Nihon Kessho Gakkaishi 46(6): 421-425.

Knesl, P., D. Röseling and U. Jordis (2006). "Improved synthesis of substituted 6, 7dihydroxy-4-quinazolineamines: tandutinib, erlotinib and gefitinib." Molecules 11(4): 286-297.

Krapf, M. K., J. Gallus and M. Wiese (2017). "Synthesis and biological investigation of 2, 4-substituted quinazolines as highly potent inhibitors of breast cancer resistance protein (ABCG2)." European journal of medicinal chemistry 139: 587-611.

Li, W., S.-Y. Chen, W.-N. Hu, M. Zhu, J.-M. Liu, Y.-H. Fu, Z.-C. Wang and G.-P. OuYang (2020). "Design, synthesis, and biological evaluation of quinazoline derivatives containing piperazine moieties as antitumor agents." Journal of Chemical Research 44(9-10): 536-542.

Marvania, B., P.-C. Lee, R. Chaniyara, H. Dong, S. Suman, R. Kakadiya, T.-C. Chou, T.-C. Lee, A. Shah and T.-L. Su (2011). "Design, synthesis and antitumor evaluation of phenyl N-mustard-quinazoline conjugates." Bioorganic \& medicinal chemistry 19(6): 1987-1998.

Marzaro, G., A. Coluccia, A. Ferrarese, P. Brun, I. Castagliuolo, M. T. Conconi, G. La Regina, R. Bai, R. Silvestri and E. Hamel (2014). "Discovery of biarylaminoquinazolines as novel tubulin polymerization inhibitors." Journal of medicinal chemistry 57(11): 4598-4605.

Marzaro, G., A. Guiotto and A. Chilin (2012). "Quinazoline derivatives as potential anticancer agents: a patent review (2007-2010)." Expert opinion on therapeutic patents 22(3): 223-252.

OuYang, Y., C. Wang, B. Zhao, H. Xiong, Z. Xiao, B. Zhang, P. Zheng, J. Hu, Y. Gao and M. Zhang (2018). "Design, synthesis, antiproliferative activity and docking studies of quinazoline derivatives bearing oxazole or imidazole as potential EGFR inhibitors." New Journal of Chemistry 42(21): 17203-17215.

Pathak, P., H. Rimac, M. Grishina, A. Verma and V. Potemkin (2021). "Hybrid Quinazoline 1, 3, 5-Triazines as Epidermal Growth Factor Receptor (EGFR) Inhibitors with Anticancer Activity: Design, Synthesis, and Computational Study." ChemMedChem 16(5): 822-838.

Peng, W., Z.-C. Tu, Z.-J. Long, Q. Liu and G. Lu (2016). "Discovery of 2-(2aminopyrimidin-5-yl)-4-morpholino-N-(pyridin-3-yl) quinazolin-7-amines as novel PI3K/mTOR inhibitors and anticancer agents." European journal of medicinal chemistry 108: 644-654. 
Qin, X., Y. Lv, P. Liu, Z. Li, L. Hu, C. Zeng and L. Yang (2016). "Novel morpholin3-one fused quinazoline derivatives as EGFR tyrosine kinase inhibitors." Bioorganic \& medicinal chemistry letters 26(6): 1571-1575.

Ravez, S., O. Castillo-Aguilera, P. Depreux and L. Goossens (2015). "Quinazoline derivatives as anticancer drugs: a patent review (2011-present)." Expert opinion on therapeutic patents 25(7): 789-804.

Sirisoma, N., A. Pervin, H. Zhang, S. Jiang, J. A. Willardsen, M. B. Anderson, G. Mather, C. M. Pleiman, S. Kasibhatla and B. Tseng (2010). "Discovery of $\mathrm{N}$-methyl-4-(4-methoxyanilino) quinazolines as potent apoptosis inducers. Structure-activity relationship of the quinazoline ring." Bioorganic \& medicinal chemistry letters 20(7): 2330-2334.

Smaill, J. B., G. W. Rewcastle, J. A. Loo, K. D. Greis, O. H. Chan, E. L. Reyner, E. Lipka, H. H. Showalter, P. W. Vincent and W. L. Elliott (2000). "Tyrosine kinase inhibitors. 17. Irreversible inhibitors of the epidermal growth factor receptor: 4-(phenylamino) quinazoline-and 4-(phenylamino) pyrido [3, 2-d] pyrimidine-6-acrylamides bearing additional solubilizing functions." Journal of medicinal chemistry 43(7): 1380-1397.

Tu, Y., C. Wang, S. Xu, Z. Lan, W. Li, J. Han, Y. Zhou, P. Zheng and W. Zhu (2017). "Design, synthesis, and docking studies of quinazoline analogues bearing aryl semicarbazone scaffolds as potent EGFR inhibitors." Bioorganic \& medicinal chemistry 25(12): 3148-3157.

Wu, H., X. Xie and G. Liu (2010). "Parallel Solution Phase Synthesis of 3, 6, 7- 4 (3 $\mathrm{H})$-Quinazolinones and Evaluation of Their Antitumor Activities against Human Cancer." Journal of combinatorial chemistry 12(3): 346-355.

Yin, S., C. Tang, B. Wang, Y. Zhang, L. Zhou, L. Xue and C. Zhang (2016). "Design, synthesis and biological evaluation of novel EGFR/HER2 dual inhibitors bearing a oxazolo $[4,5-\mathrm{g}]$ quinazolin-2 (1H)-one scaffold." European journal of medicinal chemistry 120: 26-36.

Yong, J.-P., C.-Z. Lu and X. Wu (2015). "Potential anticancer agents. I. Synthesis of isoxazole moiety containing quinazoline derivatives and preliminarily in vitro anticancer activity." Anti-Cancer Agents in Medicinal Chemistry (Formerly Current Medicinal Chemistry-Anti-Cancer Agents) 15(1): 131-136.

Zayed, M. F., H. E. Ahmed, S. Ihmaid, A.-S. M. Omar and A. S. Abdelrahim (2015). "Synthesis and screening of some new fluorinated quinazolinonesulphonamide hybrids as anticancer agents." Journal of Taibah University Medical Sciences 10(3): 333-339.

Zhang, Y., C.-R. Yang, X. Tang, S.-L. Cao, T.-T. Ren, M. Gao, J. Liao and X. Xu (2016). "Synthesis and antitumor activity evaluation of quinazoline derivatives 
bearing piperazine-1-carbodithioate moiety at C4-position." Bioorganic \& medicinal chemistry letters 26(19): 4666-4670.

Zheng, Y.-G., W.-Q. Zhang, L. Meng, X.-Q. Wu, L. Zhang, L. An, C.-L. Li, C.-Y. Gao, L. Xu and Y. Liu (2020). "Design, synthesis and biological evaluation of 4-aniline quinazoline derivatives conjugated with hydrogen sulfide $(\mathrm{H} 2 \mathrm{~S})$ donors as potent EGFR inhibitors against L858R resistance mutation." European Journal of Medicinal Chemistry 202: 112522.

$$
\begin{aligned}
& \text { مقال عن اهميه مشتقات الكينازولين كمضادات للسرطان واسعه المجال } \\
& \text { 'رضا رزق مبروك, *'محد ايمن الذهبى, 'سمر القليوبى, 'حازم عبد الهادى على, 'عبداله السيد عبداله } \\
& \text { 'قسم الكمياء الدوائيه الصيدليه وتصميم الادويه, كليه الصيدله بنين ,جامعه الاز هر, القاهره ،مصر } \\
& \text { malzahaby@azhar.edu.eg: البريد الالكترونى للباحث الرئيسى }
\end{aligned}
$$

يعد مرض السرطان واحدا من اهم اسباب الوفاه على مستوى العالم مما دفع الى تُو تطوير العديد من العقاقير

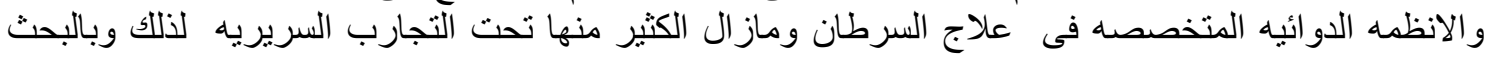

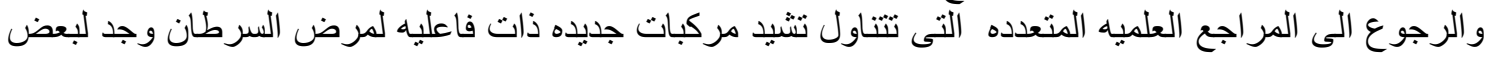

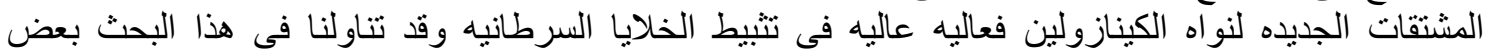

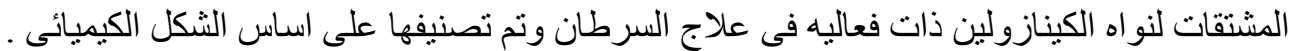

الكلمات المفتاحية : الكيناذولين , السرطان , المعدلات المناعبة , انزيم الثثميديلات , تثبيط الحمض النووي , بلمرة التوبولين 